\title{
The Efficacy of Bangun-Bangun Leaves (Coleus amboinicus) Extracts as Analgetic on Mice (Mus musculus) Induced by Acetic Acid \\ Yunita Sari Pane ${ }^{1^{*}}$, Sufitni $^{2}$ and Nurfida Alrasyid ${ }^{3}$
}

${ }^{1}$ Department of Pharmacology \& Therapeutic, University of North Sumatra, Medan, North Sumatera, Indonesia

${ }^{2}$ Department of Anatomy, University of North Sumatra, Medan, North Sumatera, Indonesia

${ }^{3}$ Department of Parasitology, University of North Sumatra, Medan, North Sumatera, Indonesia

"Corresponding author: Yunita Sari Pane, Department of Pharmacology \& Therapeutic, Faculty of Medicine, University of North Sumatra, Medan, North Sumatera, Indonesia, Tel:+ 886-2-28757296 ;E-mail: yunitasaripane@yahoo.com

Rec date: Feb 02, 2018; Acc date: Feb 25, 2018; Pub date: March 6, 2018

Retraction Note: The article entitled "The Efficacy of Bangun-Bangun Leaves (Coleus amboinicus) Extracts as Analgetic on Mice (Mus musculus) Induced by Acetic Acid," has been accepted for publication in the Journal, General Medicine: Open Access considering the statements provided in the article as personal opinion of the author which was found not having any conflict or biasness towards anything. As the article was a perspective one, information provided by the author was considered as an opinion to be expressed through publication.

Publisher took decision to make the article online solely based on the reviewers suggestion which considered the article not but a personal opinion of the author. However, it is found that the author have some personal concerns and issues, therefore, being retracted from the journal. 